Open Access

\title{
Fluctuating policy implementation and problems in grassroots governance
}

\author{
Jiajian Chen ${ }^{*}$ and Qiongwen Zhang
}

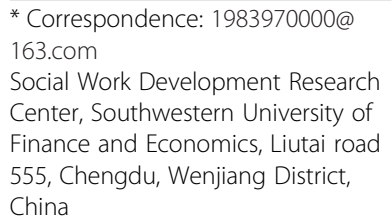

* Correspondence: 1983970000@ 163.com

Social Work Development Research Center, Southwestern University of Finance and Economics, Liutai road 555, Chengdu, Wenjiang District, China

\begin{abstract}
Both passive and campaign-style implementations of public policies are utilized in China. The alternation of the two types of implementations causes public policies to fluctuate. This article conducts a detailed case study of a dynamic policy implementation process and argues that such alternation is attributable to the environment in which grassroots governments implement policies. The root causes of passive implementation and campaign-style implementation lie in the low level of applicability of policies in the local contexts and changes in pressure from above for implementation. In addition, this fluctuating policy implementation usually accumulates to create social conflicts and governance problems.
\end{abstract}

Keywords: Public policy, Passive implementation, Campaign-style implementation, Grassroots governance

The problems in the implementation of China's public policies have long drawn considerable attention from academics and the general public; the focal concerns of which include insufficient implementation capacity and deviation from original state intentions. Yet, if observed as a dynamic process, China's public policy implementation shows obvious fluctuations. In some cases, policies are implemented loosely, while at other times, policy implementation is rather rigid; loose and rigid implementations alternate and fluctuate on a regular basis. How are loose and rigid implementations interconnected? What leads to fluctuating policy implementation, and is it related to the mechanisms of governance? What problems in grassroots governance ${ }^{1}$ will result from fluctuating policy implementation? This article addresses these three questions.

\section{Policy implementation and grassroots governance: issues and studies}

"Public policy" refers to government-made rules and regulations for the management of public affairs (Anderson 1975). ${ }^{2}$ A large number of social science research works reveal the problems in public policy implementation and their consequences. Since the 1970s, research on policy implementation has proliferated, many of which are concerned with problems in policy implementation and have generated some influential theories: topdown implementation (Pressman and Wildavsky 1984), street-level bureaucrats (Lipsky 1980), organizational theory (Van Meter and Van Horn 1975), network theory (Hall and O'Toole 2000), and institutional structuralism (Ostrom 1999). This research adopts different approaches to examine various factors that impact public policy implementation and various problems in public governance due to flawed policy implementation. We

(C) 2016 Chen and Zhang. Open Access This article is distributed under the terms of the Creative Commons Attribution 4.0 International License (http://creativecommons.org/licenses/by/4.0/), which permits unrestricted use, distribution, and reproduction in any medium, provided you give appropriate credit to the original author(s) and the source, provide a link to the Creative Commons license, and indicate if changes were made. 
thus need a theoretical explanation of the problems in public policy implementation and in turn, find ways for effective implementation (Hill and Hupe 2011).

In Chinese studies, scholars have revealed many governance problems resulting from deviation in policy implementation. For instance, township governments have levied excessive rural taxes and surcharges (santi wutong), which imposed a heavy burden on peasants and created social conflicts in the grassroots society (Cao 2004). Grassroots governments enforced demolition and relocation rules and regulations in a violent manner, creating serious social grievances (Yu 2010). In the management of urban land for construction, state agencies swing in the manner in which they implement state policies (He 2013). In environmental protection, local governments bypass state laws and regulations for their own benefit, covering up polluting factories and degrading environmental quality (Hong 2012). In sum, much research has been widely conducted on various facets of China's public policy implementation and governance problems.

There are three main perspectives adopted in such analyses. First, the interests of various levels of government are a central factor in explaining the deviation in policy implementation. In the analysis of "revenue-driven governments" (Yang and Su 2002), it has been found that for maximization of local fiscal revenues, local governments tended to implement state policies that would reduce fiscal revenues perfunctorily or even refused to implement them, causing many problems in grassroots governance (He 2008). Second, poor implementation of public policies is regarded as a serious problem that leads to the failure of central state mandates. Rigid implementation of policies is considered a good thing (Ning 2000), yet such analysis fails to realize that rigid implementation as well as loose implementation is a phenomenon of China's problematic policy implementation and is attributable to existing governance mechanisms. Third, grassroots state behaviors are the focus in explanations of deviating policy implementation and related governance problems. For example, selective policy implementation (O'Brien and Li 1999), symbolic implementation (xiangzhengxing zhixing) (Li 2012), and flexible implementation (biantongshi zhixing) (Wang et al. 2011) are theories explaining the failure of public policies from the perspective of deviating grassroots state behaviors.

Based on these three perspectives, some scholars offer recommendations for improving policy implementation, and the central argument of which is to strengthen the regulations of local governments, such as tightening supervision and evaluation, specifying the duties and obligations of local governments, and reinforcing budgetary management (Ding and Ding 2004; He and Kong 2011; Li 2012; Wang 2014). Such policy recommendations compress the maneuvering room of grassroots governments in enforcing policy implementation.

We agree with the above insightful analyses of policy implementation and governance problems in that the agency of grassroots governments in policy implementation is an important factor contributing to various methods of implementing policy. However, the perspective of local state behavior focuses on the agency of grassroots governments and neglects external impacts and constraints. In addition, it is too simplistic and potentially misleading to offer policy recommendations that claim strengthening the regulations of local state behaviors will solve the problems in public governance, and the results of such recommendations may not be satisfactory. In the latest research on policy implementation in the West, some scholars argue that problems in policy implementation should be explained in light of the interaction between institutional environments and behaviors 
rather than simply focusing on those implementing the policy (Ostrom 1999; O'Toole 2000; Sabatier 2004).

In order to understand the logic of grassroots governments' policy implementation in the context of governance mechanisms, I adopt an institutional environment perspective. For grassroots governments, two external factors exert the most significant influence on public policy implementation. The first is the applicability of policies at the grassroots levels. In China, public policies are created by the higher levels of authority but are implemented by the lower levels of authority (O’Brien and Li 1999). Thus, grassroots governments have to implement public policies that may not be fully applicable to the local circumstances. Second, the pressure for implementation is a critical factor. In different circumstances, the higher levels of governments pressure the lower levels of government in different ways, creating varying environments for policy implementation at the grassroots level. If the applicability of policies is low along with changes in pressure for implementation from above, "passive implementation" and "campaign-style implementation," which seem to oppose but are actually related to each other, will alternate and fluctuate.

This article conducts a case study of policy implementation in the coal mining industry in L County, Y City, S Province, for an in-depth analysis of policy implementation. This industry experienced a crisis in grassroots governance. In summer 2013, L County began a large-scale merger and restructuring of coal mines. As designed, the merger and restructuring would be based on laws would take care of the interests of various stakeholders, and would also provide an opportunity for economic restructuring and reducing social conflicts. With these issues in mind, all governments at the provincial, city, and county levels spared no efforts in facilitating this major "industrial upgrading and transformation." However, at this critical moment, a large-scale popular protest erupted that demanded the governments and the mines pay social insurance premiums for the last 10 years to thousands of workers. ${ }^{3}$ Group petitions, violent strikes, and judicial litigation were all used and continue to date, creating a crisis in grassroots governance and rendering the grassroots government helpless. This crisis reflects the problems in policy implementation in the coal mining industry over the last 10 years. I conducted fieldwork from late 2013 to June 2014 in L County in which data was collected through interviews, local archives, and participant observation.

\section{Passive policy implementation: circumventing laws and regulations in the industry}

The governance crisis faced by L County in 2013 can be traced back to the late 1990s, when the coal mining industry in L County was booming and dozens of coal mines employed a large, young labor force and generated considerable fiscal revenues for the county government. ${ }^{4}$ From 2003 to 2011, the coal mining industry of L County was at its apex, with the number of coal mines reaching $83 .{ }^{5}$ They produced over 6.8 million tons of coal in 2012, and the total economic output of which was approximately 3.4 billion yuan. On average, each coal mine employed 300 workers; the total number of workers employed in L County's coal mining industry from 2005 to 2012 was around 15,000 . Thus, the coal mining industry was very important to the county's economy and society, given the number of mines, total scale of production, total economic output, and total number of employees. However, a major crisis was surfacing in the coal mining industry. The biggest problem was that state laws and regulations 
governing workers' social insurance were deliberately overlooked because coal mining companies did not provide pension plans or medical care to their workers. This problem ultimately led to the crisis in 2013.

According to the Labor Law, in any employment relationship, "employers and employees should participate in social insurance plans and pay premiums" (Article 72 in the Labor Law). The Labor Contract Law stipulates that employers and employees must sign labor contracts with each other in which a clause specifying social insurance must be included (Article 17 in the Labor Contract Law). Various levels of governments wrote policies requiring employers to include their employees in the social insurance system. For instance, the State Council promulgated its "Decision on Improving Basic Pension Plans for Employees of Enterprises," and the Ministry of Labor and Social Security called for "expanding the coverage of pension plans, and protecting the social security rights of employees." In addition, L Province also wrote a policy stating that "all urban enterprises, public institutions managed as enterprises, and nonenterprise private organizations and their contracted employees" must purchase social insurance, particularly pension plans. ${ }^{8}$ However, in L County's coal mining industry, I found that such state laws and regulations governing social insurance were not included in labor contracts but were replaced with another set of agreements. A typical labor contract in the coal mining industry reads as follows:

\section{Chapter 4 Remuneration}

Article 1. Party A determines remuneration based on the wage system of the Coal Mine, may or may not be a piecework system.

Article 2. Party A remunerates party B in cash, and the last days of each month are the dates for the payment of wages of the previous month, except for special cases. Chapter 5 Social insurance and welfare

Article 1. Upon the request of party B, party A must pay all social insurance premiums for party B as included in party B's wage, and it is party B's responsibility to decide whether he or she purchases social insurance and the consequences of not purchasing should be dealt with solely by party B (except for work-related injury insurance).

Article 2. The expenses of medical treatment due to illness and nonwork-related injury must be paid solely by party B.

Article 3. Work-related injuries of party B are treated in accordance with Regulations Governing Work-related Injury Insurance and other related laws and regulations.

Article 4. Party B provides accommodation for party B and its centralized management, and party B is not responsible for the consequence of any event in which party $B$ leaves centrally managed areas of the Coal Mine without the consent of party A.

Article 5. Overtime work on Saturdays and Sundays as well as statutory public holidays is determined based on work assignment forms, and overtime pay is determined in accordance with related laws and regulations.

Article 6. Party B must obtain the permission of the Head of the Coal Mine to leave the Coal Mine, and Party B has to be responsible for any consequences of his or her leaving the Coal Mine without the permission of the Head. In such an event, party A has the right to assume that party B has resigned from his or her job. 
In L County's coal mining industry, mandatory social insurance is absent, except for work-related injury insurance. Both the employers and employees are highly concerned with the latter because work-related injuries are commonplace in the coal mining industry. Social insurance premiums are replaced with revenues of the coal mine and wages of the employees. In other words, employees' wages include social insurance premiums that should actually be used for purchasing social insurance. Based on the income levels in the coal mining industry, each employee should pay 200-300 yuan each month for social insurance. Instead, coal mines save these social insurance premiums. The average income of coal mine workers in L County is $3000-4000$ yuan, and thus, coal mines should pay 500-800 yuan each month for each employee's social insurance. For employees who are in their twenties or thirties, in-pocket wages are more valuable than a social insurance policy that may only prove valuable in the future. Hence, for both the employers and employees, it is worth circumventing mandatory social insurance regulations and breaking the law. Astonishingly, this law-breaking practice existed in L County for more than a decade and involved tens of thousands of employees.

Why was the county government absent when it is supposed to enforce laws? Did related government bureaus have no knowledge of this problem? My fieldwork showed that this was not the case; the bureaus of Labor and Social Security and Economy and Information Technology were well aware of the problem. For instance, before 2013, L County's Bureau of Labor and Social Security clearly realized that this problem existed and made efforts to establish a regulatory system overseeing social insurance, requiring enterprises to purchase social insurance and creating profiles of employees who circumvented social insurance and preventing them from finding reemployment. ${ }^{9}$ However, these efforts were in vain and the problem persisted, resulting in the crisis in 2013.

The fieldwork determined three reasons that the policy of mandatory social insurance was not implemented in the coal mining industry despite the fact that the laws and regulations were clear and the state agencies in charge were clearly aware of the problem. The first reason is irregular employment in the industry. In L County, the seasons of employment in the coal mining industry are irregular and differ considerably from other industries. The production of coal fluctuates dramatically with the market. Generally speaking, there are three seasons for coal production: several months after the Chinese New Year is the first busy season, followed by an off season in the summer, and the second busy season occurs in the latter half of the year. This causes a high level of mobility of employees. Although the workers sign a 1-year contract with the coal mines, they actually work there for half a year and spend the other half working elsewhere. The irregular and mobile characteristics of employment make it very difficult to enforce mandatory social insurance because it is hard for coal mines to purchase social insurance for their floating employees. State agencies are also incapable of overseeing social insurance for this highly mobile workforce.

The second reason is strong interjurisdictional competition. L County is located at the intersection of the borders of three provinces, with more than a dozen neighboring counties also heavily reliant on the coal mining industry. The intercounty competition is strong, one important facet of which is competition for a labor force. In order to attract workers, heads of coal mines usually cater to workers' demands by, among other things, cashing social insurance premiums for workers. This creates a dilemma for the L County government in terms of law enforcement because strict enforcement of state 
laws and regulations governing social insurance of mine workers could push workers out of the county. Within S province, L County could ask the municipality above it to coordinate all its subordinate counties to enforce laws and regulations in the coal mining industry. However, it is more complicated when coal mines in two other provinces are also involved. Thus, the L County Bureau of Labor and Social Security submitted a report to the central government suggesting a coordination agency for the coal mining regions in the three provinces but received no reply due to complicated administrative coordination. In this context of intercounty competition, the L County government acquiesces to the practice of circumventing social insurance in the coal mining industry to avoid losing workers from the county, which would negatively affect production and the county government's fiscal revenue. According to the county's statistics, $1 \mathrm{t}$ of coal generates 130 yuan of state taxes and fees. During 2010-2013, the annual average production output of coal was four million tons, which generated state taxes and fees in the amount of 460 million yuan. This was undoubtedly the major source of fiscal revenue for all counties located in this mountainous region.

The third reason is state intervention. The production of ordinary enterprises is determined by the market. The coal mining industry is different because it is heavily influenced by state intervention. Coal mines are forced to suspend production during holidays and festivals, such as a 1-month suspension during the Chinese New Year, in order to avoid industrial accidents. More importantly, in the safety-in-production regulatory system, a collective punishment arrangement (lianzuo zhidu) ${ }^{10}$ is adopted, which means an accident in one coal mine incurs industry-wide suspension and rectification in this area; the range of suspension and rectification is highly related to the severity of the accident. During my fieldwork, L County's related bureaus explained the rules of practicing collective punishment. If three or more people die in a coal mine accident, all coal mines in the county have to suspend production. If ten or more people die in a coal mine accident, all coal mines in the municipality have to suspend production. If 20 or more people die, usually all coal mines in the province have to suspend production. In 2013, a coal mine accident occurred in S province in which 29 people died. This led to suspension of production in all coal mines in S Province from May to October. All workers were unemployed during the suspension except for such safety-related work as ventilation, drainage, and gas monitoring. According to L County Bureau of Economy and Information Technology statistics, all coal mines in L County were forced to suspend production for 3 months in 2011, 6 months in 2012, and 5 months in 2013; the reasons for which were usually coal mine accidents in other counties.

The coal mining industry is therefore heavily affected by state intervention instead of operating purely in accordance with the market, which causes problems in social insurance. For instance, handling employees' social insurance when coal mines are forced by the local state to suspend production presents a difficult problem. According to the Ministry of Labor and Social Security, as long as the labor contract is valid, social insurance premiums should be paid even when enterprises suspend their business operations. However, the Ministry of Labor and Social Security does not explain whether such policy is applicable to forced suspension required by the state. If enterprises suspend production due to state intervention, enterprises are reluctant to pay their employees' social insurance premiums because enterprises are not voluntarily suspending production. During my 
fieldwork, one owner of coal mine calculated the costs of social insurance for me. Taking a coal mine employing 300 workers as an example, the coal mine has to pay 500-800 yuan per month for each worker as social insurance premiums, totaling 150,000 yuan for all 300 workers. If the coal mine suspends production for 5 months a year on average, the coal mine has to pay social insurance premiums in the amount of 750,000 yuan during suspension, which is hard for a coal mine whose profit averages three million yuan a year. ${ }^{11}$ In addition, since workers have no wages during suspension, they are unable to pay social insurance premiums. Heavy state intervention makes it difficult for the coal mining industry to enforce mandatory social insurance compared to other industries.

The related bureaus of L County were concerned about this dilemma and requested several times that coal mines purchase social insurance for their employees. However, they found that specific rules for implementation are absent in state laws and regulations. More importantly, provincial and municipal governments did not investigate this problem and exert pressure for implementation, keeping state laws and regulations at the macro level with no specific rules for implementation. In China's administrative system, a key criterion for judging whether local governments take state policies seriously is the rules for implementation created by local governments since it is difficult to implement state policies without such rules. Hence, it may indicate that local governments do not take state policies seriously if they just forward the policies to their subordinates but do not provide specific rules for implementation. This was exactly the case regarding social insurance in the coal mining industry in S Province. Moreover, L County was concerned about the difficulties of implementing state laws and regulations and put this problem aside for more than a decade. They acquiesced to coal mines and their employees circumventing state laws and regulations, thus allowing social conflicts to accumulate.

\section{Campaign-style policy implementation: the shutdown of coal mines under enormous pressure}

The State Council released its "Circular of Opinions on Accelerating Mergers and Restructuring of Coal Mines"12 in 2010, requesting nationwide rectification of the coal mining industry. The guiding principle of rectification as provided in this document is to "make full use of the market mechanism and facilitate it with state policies ... combine enforcement in accordance with laws and regulations with institutional and mechanism innovations, reduce the number of coal mines while protecting the lawful rights of workers and investors." The central objectives are to combine the market mechanism and state intervention to eliminate inefficient coal mines through selection or competition, upgrade the industrial structure, and protect the rights of investors and workers. S Province did not take the implementation of this state policy very seriously and only created its rules of implementation in early 2013. The provincial rules abide by the guiding principle of the State Council by stating that it is to "make full use of the market mechanism and facilitate it with state policies, combine centralized planning with adaption to local conditions and classified management, combine enforcement in accordance with laws and regulations with institutional and mechanism innovations, reduce the number of coal mines while protecting the lawful rights of workers and investors," ${ }^{13}$ and specify that coal mines that do not have legal mining licenses and do not meet safety-in-production criteria, coal resources-exhausted mines, and mines of which the annual production output is below 30,000 $t$ have to be shut down and rectified. This document also required 
counties specializing in the coal mining industry to create their work plans before June 2013, make initial efforts to shut down coal mines that did not have legal mining licenses and did not meet safety-in-production criteria, and complete the merger and restructuring of all coal mines by June 2015. It was repeated again and again that the interests of various stakeholders should be protected: "all localities and all departments should attach great importance to the employment of workers, carefully handle the transfers and changes of labor relations of workers ... carefully solve the problems of continuing workers' labor relations and social insurance and unpaid wages and social insurance premiums in order to protect workers' lawful rights ... and cope with problems in debts and liabilities, specify the duties of repayment of debts, and protect the lawful rights of creditors and investors."

L County welcomed the rules of implementation made by S Province in early 2013, and its bureaus of Labor and Social Security and Economy and Information Technology, which were in charge of this work, believed that the rules would enable "reasonable and lawful" rectification of coal mines. By "lawful" they meant abiding by state laws and regulations; by "reasonable" they meant protecting the rights of local governments, investors, and workers. There were thus few obstacles to implementation. In sum, L County believed that the rules provided the time for rectifying the coal mines and the industrial restructuring, and it planned to take two or three years to shut down coal mines, the smaller ones first and larger ones later, in order to reconcile conflicts and solve the problems.

In early 2013, however, a major industrial accident occurred in a coal mine in $S$ Province, which led to forced suspension of production in all coal mines in S Province for 5 months. In addition, the S Provincial Government decided to accelerate the rectification of coal mines and released the "Emergency Circular of General Office of the S Provincial Government regarding the Acceleration of Rectification and Shutdown of Coal Mines." ${ }^{14}$ This statement required each county and municipality to select the major local party-state officials to form their own work teams to efficiently carry out the rectification. Before May 2013, the S Provincial Government had set the task of shutting down 120 coal mines in S Province, of which 16 coal mines were in Y Municipality and 4 coal mines in L County. However, the accident in May pushed this number up to 400 coal mines, ${ }^{15}$ dramatically increasing the tasks of Y Municipality and L County. As a result, "management by objectives" (mubiao guanli zerenzhi) was adopted at the provincial, municipal, and county levels to rectify coal mines; in this process, the guiding principle shifted from market mechanism to state administration, and an economic task became a political task.

Some previous research has revealed the mechanism of "management by objectives," and the main features of which are that governments at the higher levels assign tasks and objectives to lower-level governments and evaluate their performance against quantitative criteria (Wang and Wang 2009). "Management by objectives" reflects the operation of the pressure-based administration (yalixing tizhi), which stimulates officials to employ a variety of methods to fulfill the tasks assigned by superiors (Rong and Yang 1998). In the rectification of coal mines in L County, "management by objectives" can be found in quantitative criteria, assigned dates of completion, and evaluation and corresponding rewards and punishment. The objective was to shut down 400 coal mines in total in 2013 in S Province. Since the number of coal mines in Y Municipality accounts for $15 \%$ of all coal mines in the province, its assigned number of coal mines was 63. Likewise, the 
number of coal mines in L County accounted for $25 \%$ of all coal mines in Y Municipality; its assigned number of coal mines was thus $16 .^{16}$ The dates of completion were all by the end of the year, when all shut-down coal mines would undergo inspection by high-level governments and archival materials would be submitted to the S Provincial Steering Group. Local party-state chiefs were to be held accountable; they had to either "finish it or get kicked out the office." 17

In this strict management by objectives, L County's original plan of "reasonably and lawfully" shutting down coal mines to smoothly reconcile conflicts and industrial restructuring became unrealistic. The new objectives demanded speedy measures to forcibly fulfill the task of shutting down 16 coal mines. Of the 53 coal mines in L County at the end of 2012, 16 had to be shut down in 2013, accounting for $30 \%$. L County took three steps to fulfill this task. The first step was regional coordination of quotas. In its analysis, the $\mathrm{L}$ County government found that the mining conditions and technology in L County were fairly good and forcibly shutting the mines down was economically unwise. L County thus decided to purchase quotas of rectification from other counties and supplement them with its own mines. Through information collection and coordination, the L County government purchased five coal mines in other counties in Y Municipality, spending 10 million yuan on average for each coal mine. The five mines had limited production output and were on the verge of shutdown and were thus willing to be sold to L County to meet its shutdown quota. ${ }^{18}$ The second step was to shut down four problematic coal mines, among which one had an industrial accident, one underwent an initial shutdown, and the other two were technically difficult to upgrade. ${ }^{19}$ There were only seven shutdown quotas remaining after the first and second steps. Since there was no widely acceptable criterion for selection, the coal mines were ranked in terms of the quantity of coal resources, and the mines ranked the lowest were forced to shut down. This practice was illegal, but given the mandates from the S Provincial Government, L County had to take extraordinary measures. According to the directive from the S Provincial Government in March 2013, these types of mines should not be shut down.

L County did not feel that the forced shutdown of coal mines was legitimate since from the perspective of law enforcement, all mines in the county had their mining licenses. However, the forceful pressure from above demanded that this task be completed. After receiving subsidies from their superiors, the county government spent a large amount of fiscal revenues to facilitate the shutdown of the mines, hoping that the high level of compensation would buy the mine owners' understanding. Compensation for shutting down mines came from provincial, municipal, and county finances. The provincial government provided four million yuan for shutting down mines with an annual coal production of 90,000 $\mathrm{t}$ and above, three million yuan for shutting down mines with an annual coal production below $90,000 \mathrm{t}$, and one million yuan for coal mines that merged with others. ${ }^{20}$ The municipal government provided supporting funds in the amount of seven million, six million, and two million yuan. Funds from the county government were solely based on production output regardless of shutdown or merger. The policy was seven million yuan for mines with an annual coal production of 90,000 $\mathrm{t}$ and above and six million yuan for mines with an annual coal production below 90,000 t. This actually encouraged a merger. When combining the three sources of compensation funds, a mine with an annual coal production of 90,000 $\mathrm{t}$ and above would receive eighteen million yuan, a mine with an annual coal production below 
90,000 t would receive fifteen million yuan, and a merged mine would receive nine million yuan.

Despite the fact that provincial, municipal, and county governments spent a large amount of fiscal funds, the standards of compensation were barely acceptable to coal mine owners. Opening a coal mine usually required an investment of over twenty million yuan; thus, the compensation did not suffice. L County added more compensation for coal mines and basically reached the amount of investment, and it also asked other mines to provide additional compensation funds based on their production output. L County government explained that sixteen mines were shut down, and thus the surviving mines would benefit from this policy; it was reasonable for them to provide additional compensation funds. The specific criterion was that each ton of coal produced since November 2013 would be levied an additional fee of 20 yuan. Based on the price of coal and the market prospects, it would take at least 3 years to levy the total amount of fees as compensation funds. Among the mines shut down in 2013, the one that received the most compensation funds was a medium-sized mine with an annual production output of $150,000 \mathrm{t}$; it received 37.6 million yuan in compensation. The three levels of budgetary funds could only provide 18 million yuan in compensation, with the remaining funds to be paid by the surviving mines. The shutdown schedule was that mines shut down by the end of August 2013 would receive the first installment accounting for $50 \%$ of the total compensation funds and mines shut down by the end of October 2013 would receive the first installment accounting for $40 \%$ of the total compensation funds. ${ }^{21}$ Only after the mines had properly handled all equipment and workers' wages and signed agreements with the government would the shutdown be considered complete and the remaining installment of compensation funds be paid. For the shutdown mines, $20 \%$ of the compensation funds were still withheld in case of additional problems, such as environmental pollution or unpaid wages. Ultimately, L County took forceful measures to fulfill the task.

In this process, the originally light rectification of coal mines was radicalized into a strict political task. The number of mines to be shut down in L County increased from 4 to 16 . The criterion for identifying the mines to be shut down also changed from only shutting down problematic mines to forcibly assigning quotas of shutdowns. All levels of government spent their own budgetary funds and deployed harsh measures to fulfill the task. However, the consequences of this campaign were that 3000 workers in the coal mining industry lost their jobs due to the shutdown, and L County's fiscal revenue was severely impacted. The sudden rise of unemployment intensified the social conflicts that had accumulated and led to a crisis in grassroots governance.

\section{The emergence of the governance crisis and its coping strategies}

In the last decade, state laws and regulations governing social insurance were not enforced in L County's coal mining industry. This problem was not evident because mines did well, workers were employed, and both parties benefited from the development of the industry. However, when many mines were shut down, this became a crisis. The large-scale shutdown of mines reduced L County's fiscal revenues by about $20 \%$. During the rectification, the government also spent more than one hundred million yuan in compensation funds, which was a heavy fiscal burden. The effects on workers were even more obvious, as the shutdown led to the unemployment of over 3000 workers, accounting for one fifth of all employees in the coal mining industry. Although the workers could not control the 
shutdown of the mines, they did have the right to ask for compensation; the starting point for protecting their rights was the social insurance issue.

The workers argued that the coal mines had continuously circumvented their responsibility to purchase social insurance for the workers and violated state laws and regulations. They claimed that since the mines were to be shut down, mine owners should pay the social insurance premiums directly to workers in compensation. Many workers had worked in coal mines in L County for a long period, some over 10 years, and thus their compensation funds would total tens of thousands of yuan. Coal mine owners opposed such demands because they believed that social insurance premiums had been paid to the workers in cash, and even though the mines were shut down, they were not required to pay compensation funds for workers' social insurance. What is more, mines did not have the money to pay. For instance, BXL Coal Mine had been in operation for almost 10 years, employing 200 to 400 workers each year. The workers were demanding 6000 yuan in compensation funds for each person/year. This would total twelve million to twenty-four million yuan per year for BXL Coal Mine, which for a mine that had already greatly suffered from the shutdown was unaffordable. Some mine owners stated that they would purchase social insurance for workers, but the precondition was that workers return their social insurance premiums included in their wages in the past. If workers returned these premiums, mine owners would pay the workers' all social insurance from the past few years. However, this proposal was rejected by the majority of workers. Since mine owners did not meet the workers' demands, the workers took collective action to pressure the county government for a solution, using three methods. The first method was litigation. Four mine workers engaged lawyers to sue the coal mines on the basis that the labor contracts signed between workers and coal mines were unlawful. The agreements between employers and employees on the payment of social insurance premiums in cash violated state laws. They claimed the coal mines were obliged to purchase social insurance for workers, and they should also pay unpaid premiums when the mines were shut down. The second method was group petition. Since the end of 2013, hundreds of workers had petitioned the county, municipal, and provincial governments dozens of times. For instance, at the end of 2013, hundreds of workers organized a motorcycle team to petition the $\mathrm{Y}$ municipal government, which gained wide attention. Petitions to the county government were commonplace and occurred frequently. The township governments located in the coal mining areas also received more than a dozen petitions. The third method was to block the work in the mines. At BXL Coal Mine, the workers' demands for social insurance premiums were not satisfied after the merger of the mine, and hundreds of workers blocked the mining work for a month. These conflicts exerted significant pressure on $\mathrm{L}$ County, resulting in the related bureaus of the county government being, in the words of the officials, "always at alert and always receiving petitions." ${ }^{22}$ The rectification of coal mines became more difficult to handle, and the improper handling may have encouraged more workers to get involved.

Based on previous experiences, there were four coping strategies for L County to utilize in this crisis. The first was to make workers' litigation more difficult. The county courthouse stated that the workers' social insurance issues varied from one another and thus should be dealt with case by case; group litigation was not accepted. The second was to contain workers' petitions; as long as there were no violent actions against coal mines or governments, petitions were allowed. The third was to coordinate various types of social 
security. For instance, funds from the new rural cooperative medical system were used to partially cover the costs of workers' social insurance premiums. In order to avoid further disputes, L County asked the coal mines to provide a breakdown of wage and social insurance premiums on the workers' pay stubs as evidence that they were coping with potential disputes. However, the actual effects were still unclear. When I was doing fieldwork from late 2013 to April 2014, the popular protests were continuing, workers' demands were not met, the coal mines were significantly impacted by the shutdown, and both parties were very dissatisfied with the government. Although L County spent a large amount of money to cope with the crisis, the direction in which the crisis would move was still unclear.

\section{The applicability of policy and the pressure for implementation}

This article focuses on why a crisis in grassroots governance occurred. The particular perspective adopted for this analysis is the relationship between crisis and policy implementation. I argue that examining only local state behaviors does not suffice, and the structural context of policy implementation must be brought in for the analysis of implementation. In the grassroots society, there are two dimensions in the structural context of policy implementation: the applicability of policy and the pressure for implementation. The applicability of policy refers to the compatibility between policies and the local grassroots conditions. If policies are compatible with these conditions, the policies are applicable and practical. In contrast, if policies are incompatible with local grassroots conditions, the policies are inapplicable and impractical. The applicability of policies affects the difficulty of implementing policy; the more applicable a policy is, the less difficult it is to implement. There are a number of factors impacting the applicability of policies, such as the quality of policy making (Ning 2000; Huang 2011), how complicated the grassroots conditions are (Wang 2008), and how complicated the bureaucratic structure is (Chen et al. 2013). This article does not discuss these factors in detail but simply provides a holistic perspective to look into the characteristics of policy implementation.

Another factor affecting policy implementation is the pressure for implementation, namely the corresponding rewards and punishment assigned by superiors. The stronger the rewards and punishment are, the more significant the pressure and the more incentive the grassroots governments feel to implement policies. There are many factors affecting policy implementation, such as economic benefits (Oi 1999) and political mobilization (Zhou and Lian 2011).

In China's grassroots society, both the applicability of policies and the pressure for implementation are complicated. In a centralized system, policies are made by the central state, which is inevitably different from local conditions and makes the applicability of policies low (O'Brien and Li 1999). Alesina and Spolaore (2003) call this the "costs of the scale of the state," while Zhou (2011) argues that it is due to the design of China's state system to uphold state authority at the cost of the effectiveness of governance. Thus, many state policies are not very applicable in the grassroots context and face serious problems of implementation.

In terms of policy implementation, the pressure for implementation fluctuates from low to high levels. While pressure for implementing some policies is low and thus policies are either poorly implemented or implemented in adaptive and flexible ways (biantong) (Wang et al. 2011), in other cases, the pressure for implementation is high in campaignlike ways (Zhou 2012). The analytical framework developed here is based on the two 
dimensions of the applicability of policy and the pressure for policy implementation, as illustrated in Table 1.

When policies are highly applicable to grassroots contexts, policies are easy for the grassroots government to accept and implement. If the pressure for implementation is low, policies are implemented slowly. Normal implementation can usually be found in policies that are not controversial, such as the Grand Western Development program (xibu dakaifa) (Wang 2014), the development of NGOs (Wang 2008), and the development of public governance projects (Chen, 2013).

However, many policies are not very applicable in the grassroots context, which leads to problems in policy implementation. If the pressure for implementation is low, passive implementation will occur, which means that the grassroots governments do not openly resist policies but implement policies perfunctorily without achieving the core objectives of the policies. As long as policies are poorly applicable and the pressure for implementation is low, passive implementation will proliferate in grassroots governance. For instance, when town and village enterprises boomed, local governments perfunctorily implemented state tax policies in order to protect local interests, with no close oversight by the superiors. This created many opportunities for local enterprises to evade taxes (Oi 1999). If policies are poorly applicable, they face considerable resistance at the grassroots level, and tremendous pressure for implementation at this point will stimulate the grassroots government to employ extraordinary methods to achieve the policy objectives in the form of campaign-style implementation. Campaign-style implementation refers to the phenomenon in which grassroots governments go beyond the scope of conventional administrative procedures and use various resources to forcefully implement policies (Zhou 2012). Campaignstyle implementation usually deviates from the original rules governing the selection of policy targets and implementation procedures and leads to "deinstitutionalization" of policy implementation (Feng 2001). This style of implementation is commonplace in China's grassroots society. For instance, since the 1980s and under tremendous political pressure, the strict family planning policy was implemented at great legal, fiscal, and human cost in order to break resistance to the policy (Yi 2013). Another example is the forced economic restructuring of town and village enterprises in the 1990s; facing strong grassroots resistance, local governments forcibly sold all collectively owned enterprises to individuals and did not allow new town and village enterprises to be formed, leading to their abrupt disappearance (Xinwang 2005).

It was found in the case of L County that the applicability of policies regarding both workers' social insurance and the shutdown of coal mines was low. State mandatory policies regarding social insurance were poorly applicable due to the problems of a highly mobile labor force, poor regional coordination, and strong state intervention in industrial production. The absence of state-designed, detailed rules for implementation made them

Table 1 Categorizations of policy implementation. Four categorizations of policy implementation: passive implementation, normal implementation (low speed), campaign-style implementation, and normal implementation (high speed)

\begin{tabular}{llll}
\hline & & Applicability of policy & \\
\cline { 3 - 4 } & & Low & High \\
\hline Pressure for implementation & Low & Passive implementation & Normal implementation (low speed) \\
& High & Campaign-style implementation & Normal implementation (high speed) \\
\hline
\end{tabular}


more difficult to implement. Pressure from the higher levels of government for implementation of state laws and regulations governing social insurance was not high, and there was no mandatory inspection of the implementation conditions. These factors led to passive implementation of policies regarding workers' social insurance in L County, with no effective solution.

The policy of shutting down coal mines was also poorly applicable to L County. Given L County's fiscal revenues, industrial structure, and employment problem, it was difficult to shut down many mines because it did not help solve the problems in this industry that had accumulated over the last decade. Due to tremendous pressure from the superiors beginning in summer 2013, L County government had to forcibly shut down and merge mines in a campaign-like style.

\section{Problems in grassroots governance as a result of fluctuating policy implementation}

If the applicability of policy is low and the pressure for policy implementation varies, policy implementation at the grassroots level often fluctuates between passive implementation and campaign-style implementation. Policy implementation fluctuates in a particular policy area; sometimes policies are implemented rather loosely and passively, while at other times, policies are implemented very rigidly in campaign-like styles. Campaign-style implementation occurred in L County's coal mining industry. State laws and policies governing workers' social insurance could not be implemented in L County, and the core objectives of the policy were not achieved. Since 2013, however, due to tremendous pressure from the central, provincial, and municipal governments regarding the shutdown of mines, the county government took harsh measures to forcibly shut down many coal mines using campaign-style implementation. The shutdown of mines was highly related to the social insurance problem because many workers were laid off, leading to workers' demands for compensation of social insurance premiums and large-scale collective conflicts.

Fluctuation in policy implementation is an important cause of many problems in grassroots governance. When policies are passively implemented, policy objectives are not achieved, and this deviation accumulates over time. The longer the passive implementation, the more organizations and people are involved and the more serious the hidden conflicts are. In a period of campaign-style implementation, however, policies are implemented at whatever cost and on a large scale, damaging the legitimacy of policies, blocking the channel for legal solutions, incurring large-scale eruption of problems, eliminating the buffer period for coordination, and exerting tremendous pressure on the grassroots society (Fig. 1).

Other research has revealed that fluctuations in policy implementation between loose and strict methods are commonplace in grassroots Chinese society, and the resultant problems in grassroots governance also proliferate. For instance, since the 1980s, local governments' extrabudgetary revenues in tax and fiscal systems increased significantly, and the institutional oversight of fiscal expenditures weakened. The tax-sharing system tightened up local governments' extrabudgetary revenue, but their continuing fiscal expenditures in the same manner brought about major debts for local governments (Zhou 2012). In the 1990s, grassroots governments were unduly reliant on rural taxes and surcharges (santi wutong) for government expenditures, despite being warned numerous 


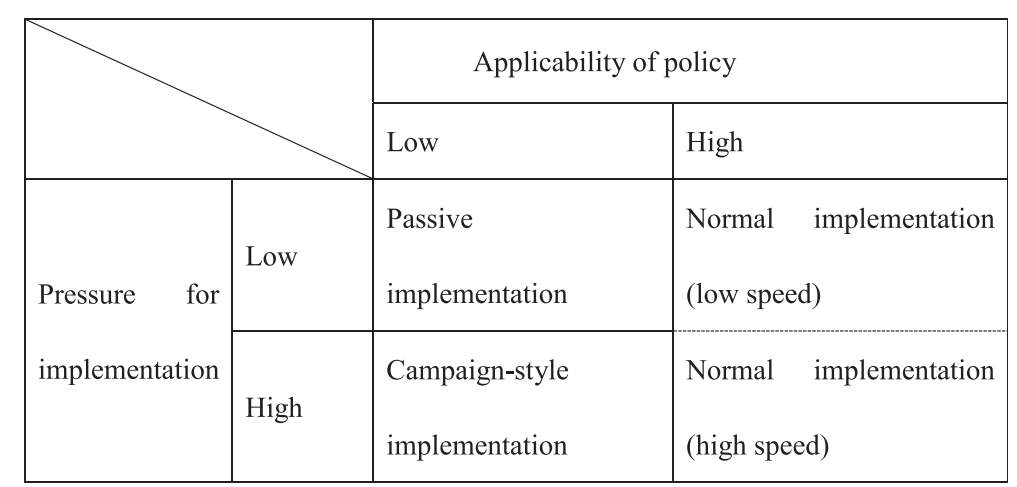

Fig. 1 Fluctuating policy implementation. Two episodes of fluctuating policy implementation: passive implementation and campaign-style implementation, causing the conflicts accumulating and erupting process in grassroots governance

times by the central state. This led to the emergence of "absorptive" (jiqu xing) local governments (Zhou 2006). In the area of financial regulation, many local governments did not regulate private lending, creating significant risks. Once the problem was uncovered, local governments banned private lending completely, jeopardizing stable financial development and local economic development (Zhang 2006; Gao and Tang 2012). In the area of letters and petitions (xinfang), the administrative methods of grassroots governments aggrieved many people; once the state affirmed the value of letters and petitions, local cases of letters and petitions surged and overwhelmed grassroots governments (Tian 2012).

\section{Conclusion and discussion}

The case of L County's coal mining industry demonstrates that grassroots governments take substantially different approaches to the implementation of public policies, fluctuating between passive implementation and campaign-style implementation. At first glance, the two approaches contradict each other, but they are actually closely interconnected. Both are the results of low applicability of policies, and grassroots governments choose from them in the context of varying degrees of pressure for implementation. The two approaches are essentially noninstitutionalized, violating the rules and procedures of public policy implementation, and thus are two sides of the same coin. Fluctuation in policy implementation is derived from the tension between a low level of applicability of policies and the varying degrees of pressure for implementation in the governance mechanism. The power of policy making is distributed from the top down, rendering many public policies poorly applicable to grassroots contexts; the performance-oriented governance mechanism makes the pressure for implementation vary from case to case (Feng 2001) and thus fluctuating policy implementation is commonplace. Both passive implementation and campaign-style implementation deviate from policy rules, undermining the effectiveness of institutions and creating problems in grassroots governance. Many conflicts accumulate and remain hidden during the period of passive implementation and intensify and erupt during the period of campaign-style implementation. Improper handling of these problems by local governments may bring about crises in grassroots governance.

It should be noted that this article provides an analysis of the empirical facts without presenting value judgments. For instance, it is not the objective of this article to discuss 
whether coal mine workers in L County should be compensated or whether it is wise to shut down many mines in a campaign-style manner. ${ }^{23}$ The case of L County is utilized simply to reveal the complicated situation of public policy implementation in grassroots Chinese society. In the case of L County, the problem in policy implementation is not due solely to the choices made by the grassroots governments but is partly due to the policy implementation context in which grassroots governments are embedded. When the applicability of policies is low and the pressure for implementation varies from low to high, policy implementation in grassroots governments can easily fluctuate and cause problems. The examination of such mechanisms is necessary for a fuller understanding of policy implementation and grassroots governance. It is not that simplistic to claim that the stricter the oversight of grassroots governments, the better the effects of policy implementation will be. In addition, since policy makers and implementers are far from each other in the administrative hierarchy, the level of applicability of policies may be very low (Zhou 2014). The stricter the oversight of the grassroots, the more probable it is that governance may fail at the grassroots level.

Many issues remain that are not discussed in this research. First, at the theoretical level, what are the reasons for the variations in the degree of pressure for policy implementation, and how are such variations transmitted within the administrative hierarchy? This is key to an in-depth explanation of the fluctuation in policy implementation. This question needs to be answered by analyzing the entire administrative hierarchy. However, due to limitations in my empirical data and research capability, I do not discuss this question in detail here but call academic attention to this question by providing an empirical research study. Second, at the analytical framework level this article briefly identifies the two dimensions of the applicability of policies and the pressure for implementation with reference to the context of policy implementation. This framework is derived from empirical data and needs more detailed elaboration of the two dimensions through further research. Third, at the empirical level, as a case study, the analytical framework and main arguments in this article need to be tested through further empirical research to determine if they can widely explain the problems in China's policy implementation. This article is only an initial attempt that invites follow-ups, feedback, and critiques.

\section{Endnotes}

"Grassroots" refers to state administration systems at the county level and below. Grassroots governance is the concrete embodiment of state administration within the society and is of particular importance (Zhe 2014).

${ }^{2}$ Based on the basic definitions of public policy in academia, this article adopts the general definition of public policy, including state laws, administrative regulations, and specific departmental rules. The point of including laws in the analysis of public policy is that law enforcement, as well as ordinary policy implementation, exerts some political pressure on the local state. In addition, laws may also be enforced passively or in campaign style. The former can be found in the enforcement of laws that govern intellectual property rights and banning pornographic products and prostitution, while the latter may typically be found in the "strike hard" (yanda) campaigns that enforce laws more harshly than the laws actually stipulate. Thus, laws and ordinary public policies can be combined for the analysis of local governance. Moreover, laws usually need 
corresponding departmental rules and interpretations for effective enforcement, rendering laws and ordinary public policies closely interconnected.

${ }^{3}$ There were also other demands, such as workers' overtime pay for holidays in the last few years. However, since these demands are easy to handle and the costs are relatively low, I do not discuss these issues in detail here.

${ }^{4}$ For the history of the coal mining industry in L County, see Interview 20140418RSJ.

${ }^{5}$ According to statistics from the L County Bureau of Economy and Information Technology (Bureau of Commerce), during 2003-2005, the number of coal mines was at its apex of 83. This number was around 50 during 2006-2012 due to mergers.

${ }^{6}$ Document No. 38 of the State Council, 2005.

${ }^{7}$ Document No. 31 of the Ministry of Labor and Social Security, 2005.

${ }^{8}$ Document No. 17 of the S Provincial Department of Labor and Social Security, 2006.

${ }^{9}$ In my fieldwork conducted in the L County Bureau of Labor and Social Security, the officials in charge defined this regulatory system as similar to a credit record system; in principal, employees who do not purchase social insurance are unable to reenter the labor market in the coal mining industry.

${ }^{10}$ The collective punishment arrangement has also been adopted in European and North American countries, but only at the enterprise level. In other words, if there is an accident in a subsidiary, its parent company and all other subsidiaries have to be rectified. In China, however, the level of applying collective punishment is industryand area-wide, particularly in such industries as coal mining, food, and fireworks and crackers, in which industrial accidents are more commonplace.

${ }^{11}$ During my fieldwork, the owner of coal mine stated that the current annual profit of coal mines is usually around three million yuan. However, profit may fluctuate along with the market.

${ }^{12}$ Document No. 46 of the State Council, 2010.

13"Opinions of S Province on Accelerating Mergers and Restructuring of Coal Mines," March 2013.

${ }^{14}$ Document No. 133 of the General Office of the S Provincial Government, 2013.

${ }^{15}$ For the list of coal mines, see "The Circular of the General Office of the S Provincial Steering Group for the Merger and Restructuring of Coal Mines regarding the List of Coal Mines to Be Shut down in 2013."

${ }^{16}$ For the list of coal mines, see "The Circular of the Y Municipal Steering Group for the Merger and Restructuring of Coal Mines regarding the Objectives of Shutting down Small-sized Coal Mines in 2013."

${ }^{17}$ Interview 20140418RSJ.

${ }^{18}$ The quality of mines in L County is higher than that of other counties in Y Municipality's coal mining areas. On the one hand, the L County Government felt it was unfair that the quotas of rectification were assigned only in quantitative terms without consideration of the quality of mines, thus incurring higher costs for L County. On the other hand, this policy also provided L County some maneuvering room because it could purchase mines on the verge of bankruptcy from neighboring counties with poor mining conditions to fulfill their task.

${ }^{19}$ The L County government's criterion was that a ten-million-yuan investment was not enough to upgrade to the new industrial standards. 
${ }^{20} \mathrm{~A}$ merger is different from a shutdown in that coal mines merge with other mines instead of being shut down completely.

${ }^{21}$ Since mine owners were dissatisfied with the forced shutdown and the government also knew that many mines had the heavy burden of repaying loans and debts, the actual first installments of compensation funds were all above $60 \%$ except for mines involved in lawsuits.

${ }^{22}$ The L County Bureau of Labor and Social Security, April 2014, "Report on the Current Conditions of Coal Mine Workers' Social Insurance."

${ }^{23}$ In fact, during my fieldwork, various stakeholders considered themselves "disadvantaged groups" whose interests were ruined, and it is hard to make value judgments. The workers suddenly lost their jobs, so they should be compensated. Coal mine owners tried to undertake technological upgrading at a huge cost in order to meet state standards but were forced to shut down and suffered great losses. The county government considered policies from the higher levels of government unreasonable but was required to implement them, only to lose significant fiscal revenues and face many social conflicts as a result of workers' petitions. The tensions between the demands of these three stakeholders reflect the complicated situation regarding policy implementation in grassroots society.

Competing interests

The authors declare that they have no competing interests.

\section{Authors' contributions}

The authors' contributions are unequal. The first author JC is responsible for writing the paper, and the second author QZ is responsible for collecting the data and government documents about the research case. Both authors read and approved the final manuscript.

\section{Acknowledgements}

This research is sponsored by the National Social Science Fund of China(15CSH049), "project system and the providing of public goods in Chinese rural areas". Earlier versions of this paper were presented to the Conference on "Urbanization and Society Building," Shanghai University, July 2013. The authors are grateful for the comments received from all participators.

Received: 28 October 2015 Accepted: 20 April 2016

Published online: 11 May 2016

\section{References}

Alesina, Alberto, and Enrico Spolaore. 2003. The size of nations. Cambridge, MA: The MIT Press.

Anderson, James E. 1975. Public policymaking. New York: Praeger.

Cao, Jinqing. 2004. Huanghe bian de Zhongguo (China along the Yellow River). Shanghai: Wenyi chubanshe.

Chen, Jiajian. 2013. "Xiangmuzhi yu jiceng zhengfu dongyuan: dui shehui guanli xiangmuhua de shehuixue kaocha" (The project system and grassroots government mobilization: a sociological study of project-based operation of social management). Zhongguo shehui kexue 2: 64-79.

Chen, Jiajian, Huimin Bian, and Xiangshu Deng. 2013. "Keceng jiegou yu zhengce zhixing" (Bureaucratic structure and policy implementation). Shehuixue yanjiu 6: 1-20.

Ding, Huang, and Mingjie Ding. 2004. "Shang you zhengce, xia you duice': Anli fenxi yu boyi qishi" ("Policies from the top, countermeasures from the bottom": case studies and implications). Wuhan Daxue xuebao (zhexue shehui kexue ban) 6: 804-809.

Feng, Shizheng. 2001. "Zhongguo guojia yundong de xingcheng yu bianyi: Jiyu zhengti de zhengtixing jieshi" (The formation and variation of China's state political movements: a holistic explanation based on regime theories). Kaifang shidai 1: 73-97.

Gao, Jinkang, and Qingli Tang. 2012. Woguo minjian jinrong guifanhua de falü guizhi (The legal regulations of China's private financing). Beijing: Falü chubanshe.

Hall, Thad E., and Laurence J. OToole. 2000. Structures for policy implementation: an analysis of national legislation, 1965-1966 and 1993-1994. Administration and Society 31: 667-86.

He, Xianming. 2008. Shichanghua jincheng zhong de difang zhengfu xingwei luoji (The logic of local state behaviors amidst marketization reforms). Beijing: renmin chubanshe.

He, Yanling. 2013. "Zhongguo tudi zhifa yaobai xianxiang jiqi jieshi" (Swinging law enforcement in China's land management and its explanation). Faxue yanjiu 6: 61-72.

He, Donghang, and Fanbin Kong. 2011. "Gonggong zhengce zhixing de Zhongguo jingyan" (China's experiences in public policy implementation). Zhongguo shehui kexue 5: 61-79.

Hill, Michael, and Peter Hupe. 2011. Implementing public policy: governance in theory and in practice, Chinese translation by Jianrong Huang et al.. Beijing: Shangwu yinshuguan. 
Hong, Dayong. 2012. "Jingji zengzhang, huanjing baohu yu shengtai xiandaihua: Yi huanjing shehuixue wei shijiao" (Economic growth, environmental protection and ecological modernization: a environmental sociology perspective). Zhongguo shehui kexue 9: 82-99.

Huang, Yi. 2011. "Gonggong zhengce zhixing piancha fenxi ji duice yanjiu" (The deviation in public policy implementation and its countermeasures). Masters thesis, Shanghai Jiao Tong University.

Li, Ruichang. 2012. "Zhongguo gonggong zhengce shishi zhong de 'zhengce kongzhuan' xianxiang yanjiu" (A study of the phenomenon of "policies on paper" in China's public policy implementation). Gonggong xingzheng pinglun 3: 59-85.

Lipsky, Michael. 1980. Street-level bureaucracy: dilemmas of the individual in public services. New York: Russell Sage.

Ning, Guoliang. 2000. "Lun gonggong zhengce zhixing piancha jiqi jiaozheng" (The deviation in public policy implementation and its correction). Hunan Daxue xuebao (shehui kexue ban) 3: 95-98.

O'Brien, Kevin J., and Lianjiang Li. 1999. Selective policy implementation in rural China. Comparative Politics 31(2): 167-86.

Oi, Jean C. 1999. Rural China takes off: institutional foundations of economic reform. Berkeley: University of California Press.

Ostrom, Elinor. 1999. Institutional rational choice: an assessment of the institutional analysis and development framework. In Theories of the policy process, ed. Paul Sabatier. Boulder, CO: Westview.

O'Toole, Laurence J. 2000. Research on policy implementation: assessment and prospect. Journal of Public Administration Research and Theory 10(2): 263-88.

Pressman, Jeffrey L., and Aaron Wildavsky. 1984. Implementation, 3rd ed. Berkeley: University of California Press.

Rong, Jingben, and Xuedong Yang. 1998. Cong yali xing tizhi xiang minzhu hezuo xing tizhi de zhuanbian (The transition from pressure-based administration to democratic-collaborative administration). Beijing: Zhongyang bianyi chubanshe.

Sabatier, Paul. 2004. Theories of the policy process, Chinese translation by Zongchao Peng. Beijing: Sanlian chubanshe.

Tian, Xianhong. 2012. Zhili jiceng Zhongguo: Qiaozhen xinfang boyi de xushi (1995-2009) (Governing grassroots China: a narrative of letters and petitions in the Qiao Township [1995-2009]). Beijing: Shehui kexue wenxian chubanshe.

Van Meter, Donald S., and Carl E. Van Horn. 1975. The policy implementation process: a conceptual framework. Administration and Society 6(4): 445-88.

Wang, Ming. 2008a. Zhongguo minjian zuzhi 30 nian: zouxiang gongmin shehui (The development of Chinese NGOs in the past 30 years: towards a civil society). Beijing: Shehui kexue wenxian chubanshe.

Wang, Shaoguang. 2014. Zhongguo, zhidao (China, governance). Beijing: Zhongguo Renmin Daxue chubanshe.

Wang, Hansheng, and Yige Wang. 2009. "Mubiao guanli zeren zhi: Nongcun jiceng zhengquan de shijian luoji" (Management by objectives: the practical logic of rural grassroots governments). Shehuixue yanjiu 2: 61-92.

Wang, Hansheng, Shiding Liu, and Liping Sun. 2011. "Zuowei zhidu yunzuo he zhidu bianqian fangshi de biantong" (Adaptation as the means of institutional operation and variation). In Zhongguo shehuixue wenxuan, ed. Xing Ying et al., 554-83. Beijing: Zhongguo Renmin Daxue chubanshe.

Xinwang. 2005. Sunan moshi de zhongjie (The end of the Sunan model). Shanghai: Sanlian shudian.

Yang, Shanhua, and Hong Su. 2002. "Cong 'daili xing zhengquan jingyingzhe' dao 'mouli xing zhengquan jingyingzhe': Xiang shichang jingji zhuanxing beijing xia de xiangzhen zhengfu" (From "proxy administrators" to "revenue-driven administrators": township governments against the background of market transition). Shehuixue yanjiu 1: 17-24.

Yi, Fuxian. 2013. Daguo kongchao: Fansi Zhongguo jihua shengyu zhengce (A big country with an empty nest: reflections on China's family planning policy). Beijing: Zhongguo fazhan chubanshe.

Yu, Jianrong. 2010. Kangzheng xing zhengzhi: Zhongguo zhengzhi shehuixue jiben wenti (Contentious politics: basic issues in Chinese political sociology). Beijing: Renmin chubanshe.

Zhang, Xiang. 2006. "Hehui de xinxi huiju jizhi: laizi Wenzhou he Taizhou deng diqu de chubu zhengju" (The information collection mechanism in rotating savings and credit associations: initial evidence from Wenzhou and Taizhou areas). Shehuixue yanjiu 4(2006): 59-85.

Zhe, Xiaoye. 2014. "Xianyu zhengfu zhili moshi de xin bianhua" (New changes in the model of county governance). Zhongguo shehui kexue 1(2014): 121-39.

Zhou, Feizhou. 2006. "Cong jiqu xing zhengquan dao 'xuanfu xing' zhengquan: Shuifei gaige dui guojia yu nongmin guanxi zhi yingxiang" (From absorptive governments to "floating" governments: impacts of tax and fees reform on state-peasant relations). Shehuixue yanjiu 5: 1-38.

Zhou, Xueguang. 2011. "Quanwei tizhi yu youxiao zhili: Dangdai Zhongguo guojia zhili de zhidu luoji" (Authoritarian regime and effective governance: the institutional logic of contemporary Chinese government). Kaifang shidai 10: 67-85.

Zhou, Feizhou. 2012a. Yi li wei li: Caizheng guanxi yu difang zhengfu xingwei (Compound interest: fiscal relations and local state behaviors). Shanghai: Sanlian shudian.

Zhou, Xueguang. 2014. "Cong 'Huang Zongxi dinglü' dao diguo de luoji: Zhongguo guojia zhili luoji de lishi xiansuo" (From "Huang Zongxi's Law" to the imperial logic: the historical thread of the Chinese government). Kaifang shidai 5: 108-32.

Zhou, Xueguang, and Hong Lian. 2011. "Zhengfu neibu shangxiaji bumen jian tanpan de yige fenxi moxing: Yi huanjing zhengce shishi weili" (A model of inter-government negotiation between superiors and subordinates: a case study of environmental protection policy implementation). Zhongguo shehui kexue 5: 80-96. 